\title{
CONSEQUENCES OF COVID-19 FOR KOSOVO'S IMPLEMENTATION TO V4+
}

\section{Gabriela Antošová1* , Helmuth Yesid Arias Gomez ${ }^{1}$, Arber Dallku², Sebastian Thoma ${ }^{3}$}

\author{
${ }^{1}$ Czech Technical University, Masaryk Institute of Advanced Studies, Czech Republic \\ ${ }^{2}$ Häme University of Applied Sciences, Finland \\ ${ }^{3}$ Catholic University of Eichstätt-Ingolstadt, Germany
}

\begin{abstract}
The article aims to provide a micro- and macro-level of a problem definition focused on Coronavirus crisis impacts on the tourism industry in the V4 countries and the eventual Kosovo integration into the V4 as a part of the Western Balkan 6 (WB6) and Eastern Partnership (EaP) enlargement $\mathrm{V}^{+}$. The analysis of the primary data and the search for results are based on the Delphi method providing a better explanation of economic, social and market integration processes which fully exploit the opportunities of the content analysis provided by the quantitative and qualitative secondary data. The article offers key guiding criteria for deepening the economic integration into the V4 Group, emphasizing key aspects such as the economic and regional convergence, and the incorporation of diverse social strata into the economic growth process. The article highlights the benefits derived from the full membership of the actual V4 Group in the European Community as well as identifies its powerful strength and stable frame for promoting growth and prosperity. The critical view of the political and economic integration process emphasizes the risks derived from the deepness of divergence across countries and regions.
\end{abstract}

Keywords: PASTA analysis, Visegrad Group countries+ $\left(\mathrm{V4}^{+}\right)$, Coronavirus, tourism industry, political integration

\section{Introduction}

The Visegrad Group countries are located in the central and northern part of Europe bordering with other European countries but also with Russia. Why have the V4 been created? The countries in the V4 have a common geographic location (Butkus, Mačiulytė-Šniukienè and Matuzevičiūtè, 2020) and territorial inequalities (Kuttor, 2009; Sucháček, 2018), history as well as similar traditions and culture (Smith, 2007), and this cooperation has been established based on the shared common values. The Visegrad Group was founded in 1991 in Hungary when three countries (Czechoslovakia, Poland, and Hungary) signed an agreement for cooperation; two years later, Czechoslovakia split into two countries, the Czech Republic and Slovakia (Declaration on cooperation 1991). The main purpose of this union was to have close political, economic and cultural cooperation among the Visegrad countries for achieving the re-integration into Europe with more than 30 years of successful cooperation (Schmidt, 2016). With tourism being one of the biggest industries in the world, the V4 countries recognized the role of tourism in their economies and set up their national tourism organizations (Abrhám, 2014; Radics and Pénzes, 2014). These organizations are responsible for destination marketing and promotion (Bačík et al., 2019a), improving the image of the country as a tourism destination and maximizing revenues from tourism (Bačik et al., 2019b). After communism collapsed, the Czech Republic, Hungary, Poland, and Slovakia also recognized the need for establishing institutions in charge of coordinated development (Péter and Zahorcsák, 2018) and cooperation (Dangerfield, 2008) and obviously promotion of tourism (Light, Dumbraveanu and Andone, 1997; Ward, 1998), so they set up a national tourism organization including transport cooperation (Taylor and (iechański, 2020).

Although these four countries are all situated in Central Europe, each of them has a slightly different economy, society and cultural heritage (Rátz, 2004; Dugulan et al., 2010; Studzieniecki, Meyer and Wanagos, 2018). These factors have, likewise, influenced tourism development (Faracik, 2014; Aubert, 2001) and ways in which they have established structure and management of their respective national tourism organizations (Hughes and Allen, 2005). Despite that, there are many similarities in how these organizations operate (Visegrad Group, 2020a; Visegrad Group, 2020b). Nowadays the tourism market reflects the Coronavirus crisis (Greve, 2020; Rickly, 2020) and negative impacts connected with state regulation systems (Krieken, 2020) for the elimination of the CoV2-SARS virus. This article is composed of a macro- and micro-level analysis: PASTA, PESTLE and SWOT analyses that help understand sustainability of the Visegrad Group enlargement and its tourism market reintegration processes.

\section{Material and methods}

The secondary and primary data for the study were collected from March 2020 to July 2020 . We provide a content analysis of the secondary data. We obtained the primary data by using qualitative techniques with the Delphi method (Skulmoski, Hartman and Krahn, 2007) because we had incomplete knowledge about the status of the tourism industry in Kosovo and its future integration into the V4 during the pandemic crisis of CoV-SARS2. We used one part (Delphi pilot study) in combination with the Classical Delphi method (Rowe and Wright, 1999) and the three-round qualitative Delphi process (Adler and Ziglio, 1996) to develop a complex situation about the integration of Kosovo into the V4 after the Covid-19 crisis. The Delphi pilot study was developed as a result of simultaneous interviews with 8 experts from Finland, Kosovo, the Czech Republic, and Germany. Experts were selected by reference and through a snowball sampling procedure. Each interview was anonymous and based on moderated three research questions: how has Covid-19 affected the tourism market of the Visegrad Group (V4), which relations do V4 have between Western Balkan and Eastern Partnership countries during the pandemic situation, and how may Kosovo integrate into the $\mathrm{V} 4$ in the future? The findings from the secondary content analysis and primary data from the interviews were "merged" during the macro- and micro-level PASTA, PESTLE and SWOT analyses; therefore, we viewed these complex relations as a whole. The combination of the three approaches had a positive impact on our 
research for future recommendation. The first approach enabled us to observe how to tackle the impact of limitations after the pandemic in the tourism industry (Antošová, 2020) and how the future integration of Kosovo into the V4 is constructed in mutual interactions among the countries.

\section{Results and discussion}

A PASTA Analysis helps businesses, corporations, and countries determine their operational plans, strategies, and what kind of measures and analyses should be used for defining and solving issues (Smith and Zook, 2016). When identifying how Coronavirus has affected the V4 tourism market, the PASTA model is used to check main damages caused by Covid-19 in the tourism market as well as the steps that could be taken for improving the tourism market (Smart Insights, 2017).

\section{Problem definition}

The virus arrived in the Visegrad countries in early March 2020, causing many difficulties in the tourism market for the four countries. Moreover, in the middle of March, the V4 countries started closing their borders, cancelling many flights, sending tourists back to their home countries, asking their residents to return from abroad. Since the middle of March, the tourism market started decreasing dramatically in all four countries, especially in the Czech Republic and Poland. The V4 countries took action immediately when the virus showed up in first cases and they started following the examples of South Korea, Japan, and South East Asia countries. However, in the V4 countries, the virus has mostly affected the tourism market compared to other businesses and operations in these countries (Bault, 2020; Visegrad Group, 2020c).

\section{Analysis}

The damages caused by Coronavirus in the tourism market in the V4 countries are huge. The most affected country by the virus is the Czech Republic since it is the first top destination for tourists in the V4 countries and the first country to have experienced initial cases of the virus. In the middle of March, the Czech Republic as well as all V4 countries announced a state of emergency by closing schools, main tourist attractions, hotels, apartments, cancelling flights, main events, etc. By closing many businesses due to the Coronavirus outbreak, a lot of people in all V4 countries lost their jobs. This tragedy has had a huge impact on the tourism market in the V4 countries long term as it has first and foremost affected prices, employees, tourists, tourist destinations, etc. As a result of Covid-19, the V4 countries imposed a quarantine, entry bans and other restrictions also for tourists as well as prevented their own citizens from travelling to other countries without a significant reason. With a decreased willingness to travel, these restrictions led to a negative impact on the tourism market in all V4 countries. Poland has announced estimated losses the tourism industry might have as a result of Coronavirus reaching up to $222.8 \mathrm{M}$ euro. Hungary also announced losses of up to $40-50 \%$ of tourists for March and April 2019 compared to last year. Tours and conferences were cancelled due to the Coronavirus outbreak in Slovakia as well, which has impacted the tourism market hard, but no estimated loss has been announced from the Slovakia government yet.

\section{Strategy}

All V4 countries have implemented strategies for battling Coronavirus in the tourism industry. The group in the tourism industry most affected by Covid-19 includes small and medium size businesses such as: hotels, AirBnb apartments, sightseeing tours, main attractions, museums, etc. Such affected businesses are always asking for financial help from the government with paying their rents, employees, and preventing bankruptcy. They are informed by the government about the latest developments via social media, e-mails, and TV channels. To achieve the objective, i.e. not to let tourism businesses go bankrupt, the V4 countries' plan is to start slowly reopening hotels, tours and museums while prescribing added caution such as social distancing, wearing facemasks in public, etc.

\section{Tactics}

The communication from the $\mathrm{V} 4$ countries to the main tourism businesses is going to be through social media, newspapers, magazines, and TV channels. Moreover, these businesses are going to get the latest information from official government announcements and decisions through the channels mentioned above. The official government decisions for each V4 country will take further steps on recuperating the damages caused by Coronavirus in the tourism industry. The V4 countries governments will help financially all tourism businesses mostly affected by Covid- 19 .

\section{Action}

Not only the V4 countries but the whole EU started taking action to reopen businesses in all industries including tourism. On $14^{\text {th }}$ April, libraries and small kiosks began their operation with an approval from the government. As of $4^{\text {th }}$ May, people were allowed to move freely but with masks on and keeping distance between each other; on that day clothes, textile and street stands also started opening their businesses. On 18 ${ }^{\text {th }}$ May, the Czech Republic started to reopen bars, restaurants, and hotels. Two weeks later, on $31^{\text {st }}$ May, football and other sport championships began again. And it is forecast that next year in March 2022, the borders will open, and everything will be over. These actions all depend on how the situation is dealt with and how fast the current situation is back to normal.

\section{Kosovo macro-level aspects}

Findings were also informed by expert views on political, economic, social, technological, legal, and environmental aspects (PESTLE). Kosovo has a parliamentary democracy. The prime minister Albin Kurti, also the head of the government and multi-party system, has been in position since February 2020 (Kosovo, 2020). There are tensions in the northern part of the country where mainly Serbians live (Bertelsmann Stiftung, 2018). This part of the population also boycotted elections in the past. In Kosovo there is a separation of power, but this presents issues as the judiciary is highly corrupt.

The economy in Kosovo is growing but there is a high dependency on Diaspora, mainly Germany and Switzerland. The currency is euro, yet the country is not a member of the European Union. Kosovo is one of the poorest countries in Europe and huge parts of the GDP are related to, as mentioned earlier, Diaspora or donor financial aid and activities. The unemployment rate is around 40\% (Kosovo, 2020). In 2017 the unemployment rate was projected to be $27.5 \%$ in 2020 . Mainly young people are jobless. One big problem of Kosovo is that it is not fully integrated into global trade flows. Its biggest trade partner is the EU (Bertelsmann Stiftung, 2018). Kosovo has the worst rank in the Corruption Perception Index in comparison to the whole Visegrad Group: with a value of 36 it ranks $101^{\text {st }}(\mathrm{CPI}, 2019)$.

With regards to the sociological factors, it must be said that Kosovo has 1.7 million inhabitants and a life expectancy of 69.0 years. According to the Declaration of Independence adopted in 2008, the majority of the population are Albanians amounting to around $90-92 \%$. The major religious group are 
Muslims. In addition, migrations of different populations (Joireman, 2017; Gollopeni, 2015), caused by various conflicts and wars, resulted into many different influences on Kosovo traditions and culture. The population growth rate is $0.8 \%$ (Bertelsmann Stiftung, 2018). The investment in the education systems is too low, so Kosovo must spend more on developing its strategies (Tahirsyzaj, 2010). Also, the property rights for minorities and women are poorly defined.

The technological part of the analysis includes an important factor, the nationwide broadband Internet access. This high-speed internet is also available at a low price in comparison to the EU average. But the road infrastructure needs upgrading (Ramadami et al., 2011). Thus, these deficits must be improved to be able to compete both in local and regional as well as in European and international markets. Therefore, the government must support this problematic field with more funding which will boost the economy and will also raise the wealth of the country sustainably (Bertelsmann Stiftung, 2018).

The citizenship is guaranteed to everyone by law. But not everybody wants to be a Kosovo citizen because this would mean a recognition of independence of Kosovo. Also, freedom of association and assembly is granted by law (Kohl, 2009). Journalist sources are protected and there is a law on press freedom and freedom of expression but for example online media are not regulated. Black market activities in Kosovo are active (Sörensen, 2006; Lewis, 2010). The environmental aspect is not that much taken into consideration by the government. Economic growth and job creation are more important. There are also no strategies to reduce $\mathrm{CO}_{2}$ emissions and the necessary waste management is missing (Bertelsmann Stiftung, 2018). In Kosovo, the reliability of electricity and water systems must be improved. The construction of a new power plant is planned to ensure electricity supply. In most parts of the country crime and violence rates are low (Kosovo, 2020).

\section{Micro-level analysis of the performance of Kosovo and integration into the Visegrad Group}

This SWOT Analysis is used to identify how the Visegrad Group should and could help Kosovo's integration into the Group. First, the performed analyses for Kosovo are shared and afterwards the recommendations for action about the possible membership of Kosovo in the Visegrad Group are given.

One of the strengths of Kosovo is that its currency is already euro. Also, the availability of high-speed Internet across the whole country is very positive and can be used for example to develop economic activities and education. The economic growth must be mentioned in respect to strengths as well. But the strengths are not very many (Doli and Korenica, 2010). One of the main weaknesses of Kosovo is a high corruption level. In addition, the unemployment rate is very high; especially many young people are jobless. Because of Diaspora, Kosovo is financially dependent on other countries (Koinova, 2018), mainly Switzerland and Germany. Another weakness is poor road infrastructure.

There are several opportunities in Kosovo. The country has a parliamentary democracy and low rates of crime and violence in most parts of the country. In addition, due to the blending of different cultural values and traditions, various inputs can be used sustainably. Especially when it comes to cultural tourism, this can be a big opportunity. Sometimes it can also be an opportunity to have many young jobless people, because this will stimulate their ability to create innovation. Another chance is that the enlargement of the Group supports stability, security, and democracy in the Group. This can be also related to the enlargement of the EU (Gotev, 2019). The tension in the northern part of the country is a threat for sure, and the fact that everybody can become a citizen could be a problem in the future. It is important to focus on the economic progress for Kosovo, but there also must be environmental awareness to ensure resources and prevent more problems in the future. How other countries perceive Kosovo can be a problem. Slovakia for example does not acknowledge the independence of Kosovo. Furthermore, the history of the country (e.g. wars) can be a problem.

\section{Kosovo's integration into the Visegrad Group}

For the Visegrad Group there are many different opportunities to support Kosovo in joining the Group. One essential point is that the larger the Group, the more stable and secure it will be. The number of conflicts and disagreements will decrease if more countries follow common interests as a group, and therefore, negative external influences are reduced. Accordingly, it would be good for the Visegrad Group to enlarge the Group and add Kosovo to the Group (Plevák et al., 2019). But there are also difficulties. Regarding economy, the Visegrad Group must support and promote Kosovo. The Group must include it in trade flows, help it develop its infrastructure and reduce its unemployment rate. This could be possible by supporting new innovations as well as borrowing money because Kosovo is one of the poorest countries in Europe.

Every member of the V4 could promote Kosovo as a tourism destination. Therefore, it will be necessary to reduce the political tensions in the northern part of the country to make tourists feel that they are safe during their travel (Kosovo, 2020). The Visegrad Group countries want to strengthen their regional cooperation. The more members the Group has, the more it will contribute to the reunification of Europe. Simple things like using a common infrastructure are steps in the right direction. Therefore, the Visegrad Group must help Kosovo to improve its infrastructure and build on the available resources, such as the nationwide Internet (Visegrad Group, 2009). For Kosovo it is important that it does its "task" and comply with conditions (Plevák et al., 2019).

\section{PASTA analysis for Kosovo and its integration into the V4 Group}

The PASTA model is used to analyze and evaluate further possibilities and challenges of the Kosovo's future integration into the European Union and the V4 Group.

\section{Problem definition}

Kosovo is one of the newest countries in the world and it is located in the Balkan territory with other countries such as Albania, North Macedonia, Serbia, Montenegro, and Bosnia \& Herzegovina. Moreover, all these countries together create WB6 (Western Balkan). The majority of the population in Kosovo is young and these people are dedicated to changing the situation in Kosovo. Kosovo is an underdeveloped country and is continuously growing. Corruption is still high and this is affecting Kosovo population in general, as well as its economic, social, environmental, and political growth. The European Union, together with the V4 Group and the USA, is helping Kosovo citizens as well as its government in the area of various grants and projects, education system projects, innovation, environmentally friendly projects, social aspects, etc. The main problems that Kosovo is facing at the moment are corruption, unemployment rates, and waste management. The V4 Group has shown interest to improve these areas and reduce these problems by helping Kosovo financially and creating many projects focused on finding solutions for waste management, unemployment, and corruption (Visegrad Group, 2017). 


\section{Analysis}

One of the main goals of the Kosovo government is to enter the European Union and become a Schengen country. For accomplishing this goal Kosovo has asked for help from the V4 Group as well as from the EU on taking the steps required for entering the EU and achieving visa liberalization. The V4 Group plays a big role in the future of Kosovo in terms of innovation, development, and full integration into the EU and the V4 Group. Moreover, KFOR troops are still operating in the country and all V4 countries have their military people there, which keeps Kosovo citizens safe. In addition, the V4 Group countries have their embassies and councils in the territory of Kosovo where they work towards further integration of Kosovo in the EU and V4. Several projects were launched by the V4 countries to address the challenges and future plans for better cooperation between Kosovo and the V4, etc. The Visegrad Group is ready to promote the integration of Kosovo throughout the EU and visa liberalization, including the handling of its membership application. In order to enhance the local administrative capacity of Kosovo, the V4 countries are ready to make full use of their present experience with twinning cooperation and offer joint V4 twinning projects for partners from the Kosovo region.

\section{Strategy}

Kosovo created a new government in February 2019; the elections held in October decided who is in charge and which party leads. The V4 have announced to the new government of Kosovo to immediately and fully resume the efforts to further the European Reform Agenda and other criteria deriving from the Stabilization and Association Agreement. Kosovo, by resuming these efforts, will start moving toward integration into the EU and the liberalization of visas. The V4 Ministers also highlight the importance of making good use of the Stabilization and Association Agreement and the EU programmes as well as ratifying the boundary agreement with Montenegro and strengthening the area of the rule of law as crucial prerequisites for the introduction of a visa-free regime in Kosovo. At the same time, the V4 also emphasized that the implementation of all agreements arising from the dialogue with Belgrade is essential for Kosovo's progress on its European path. Every year, the V4 Group accepts students from Kosovo and WB6 countries to study at their universities using Visegrad funds; the Group provides students with different grants to make it easier for them to study. It mainly wants to strengthen the trade and economic cooperation with Kosovo through opportunities in energy and infrastructure sectors. By this, Kosovo will start accelerating its economic growth and general development and have better opportunities to fully integrate into the V4 and the EU. The Visegrad Group supports Kosovo in its determination to maintain stability in the region, strengthen the rule of law, fight organized crime and corruption, enhance resilience to hybrid threats, prevent radicalization, and keep the migratory movements under control.

\section{Tactics}

The integration of Kosovo into the V4 and the EU would be beneficial for all, especially for Kosovo. The V4 Group can contribute to integrating Kosovo in the V4 by helping Kosovo financially in projects related to the environment, unemployment reduction, and implementation of strategies directly in the government of Kosovo. Advertising the projects and plans that the countries collaborate on can increase the interest among the country investors as well as the population. The increased interest of population and the investors will make the projects fully executed with the highest benefits of course if the projects are for the best of Kosovo's population and V4 Group interests.
Successful advertising of the projects and ideas will lead Kosovo to further integration into the V4 and the EU and is usually conducted via social media, street advertising, TV, and newspapers (Visegrad Group, 2019).

\section{Action}

The V4 Group, together with Kosovo, has been undertaking all the actions for accelerating the integration of Kosovo into the V4 Group and the EU. Since Kosovo is a free and independent country, the V4 has been investing and donating a lot of money to fight and solve the current problems in Kosovo. The V4 countries have sent their army troops to Kosovo for protecting and patrolling as well as keeping the citizens safe, even though now the situation is much better compared to 20 years ago. All the projects, donations and interest shown to Kosovo as well as investments are carried out for the reason to help Kosovo to achieve full integration into the EU and the V4 Group (Visegrad Group, 2009, 2017).

\section{Conclusions}

With regards to the economic growth, not the speed of the growth but its sustainability must be a priority. The unemployment rate should only continue to fall. Another important step would be that Hungary, Poland, and the Czech Republic follow Slovakia and adopt euro. Regional disparities should be reduced. The focus must be on smaller cities and rural areas as well, not only on bigger cities.

Therefore, the infrastructure, especially the road infrastructure, must be further improved. But it would also have a positive effect if the Internet access would be available nearly everywhere in the whole region. Education should be accessible for everyone. Particularly social minorities (mainly Roma) have disadvantages in this area. There should be the same opportunities for everyone. Another important recommendation is that democracies should be real democracies without any deviations. The people should have all their rights all the time, the CPI level must be improved and maybe one important step in the right direction would be transparency of political decisions. Another essential change is that the environmental awareness must be a priority in the future. Renewable energies and waste recycling should be anchored in the environmental strategies.

In conclusion, the most important thing for the Visegrad Group is to focus on its own strengths and opportunities. In addition, it is essential to act as a community and promote the region as a tourist region to specific target groups. A higher cooperation level with the EU could be an advantage for the whole Group as well. In summary, it can be said that the Visegrad Group has a high potential, especially because of the wide range of tourist offers, but some strategies need to be changed and more responsible action is required.

Nowadays another important point is entrepreneurship. For example, entrepreneurship is a solution to address youth unemployment. Jobs can be generated and contribute to economic development (Holienka et al., 2016). But with regards to entrepreneurship (Mura et al., 2017) and starting own businesses, there are still obstacles. The society has a fear of failure mentality and there is no acceptance of failure. Due to the fact that many people think they are losers if they are not successful or even fail, many potential entrepreneurs do not feel confident to try and run their own business, or even elaborate their business concepts and promotion management (Wanagos, Smalec and Studzieniecki, 2018). Therefore, the task for the Visegrad Group as well as for Kosovo is to promote young people who want to become entrepreneurs, who can change issues around sustainability and generate added value for the tourism sector, the society, the policy, the economy, etc. 
The enlargement of the Visegrad Group by for example Kosovo or other countries from WB6 or EaP will not be easy because every member must accept new members and they have to follow common interests. But the enlargement of the Visegrad Group would be a step in the right direction towards the reunification of Europe. Also, the more members the Visegrad Group has, the more its countries can promote each other, especially in the tourism sector. For an enlargement there must be cooperation and trade flows among the participating members. Also, there must be an equitable distribution of power because the members have different economic powers. For example, Kosovo is poor compared to the Czech Republic or Poland, so it will depend on these countries with respect to economic activities. But this cooperation will boost economy in smaller and poorer countries and develop them in a sustainable way. The problem is that Kosovo is not the first choice for the enlargement of the Visegrad Group. Serbia is, for example, more interesting and profitable for the whole Group. In addition, a high corruption level and poverty can be a problem for the membership; as well as the fact that Slovakia does not recognize the independence of Kosovo. Kosovo will first have to do its "task" and develop itself to be able to join the Group.

In 2020 and the following years it will be important for the Visegrad Group to have a sustainable economic growth, especially in the tourism sector. Once tourism returns to normality, the Visegrad Group's task will be to ensure that capacities, especially in large cities such as Prague, are not immediately blown up. Tourism, as well as other sectors, must also be made sustainable. "Overtourism" is an omnipresent problem and therefore strategies need to be modified to deal with the ever-changing challenges. The whole Visegrad Group has such varied tourist offer. Therefore, the task will be to market many things so that tourists do not concentrate on just a few destinations.

\section{References}

Abrhám, J. 2014. Clusters in tourism, agriculture and food processing within the Visegrad Group. In Agricultural Economics, vol. 60, 2014, no. 5, pp. 208-218.

Adler, M. - Ziglio E. 1996. Gazing into the oracle: The Delphi Method and its application to social policy and public health. London : Jessica Kingsley Publishers, 1996.

Antošová, G. - Vogl, M. - Schraud M. 2020. Challenges for the Visegrad group - The Coronavirus and its impact on tourism. In Visegrad Journal on Bioeconomy and Sustainable Development, vol. 9, 2020, no. 1, pp. 28-32. http://doi:10.2478/vibsd-2020-0006

Aubert, A. - Jónás-Berki, M. - Marton, G. - Pálfi, A. 2014. Region specific characters of tourism in east-central-europe.' In: Radics, Z. - Pénzes, J. (ed.) Enhancing competitiveness of $\mathrm{V} 4$ historic cities to develop tourism - Spatial-economic cohesion and competitiveness in the context of tourism. Debrecen : Visegradfund, 2014.

Bačik, R. et al. 2019a. Marketing instrument of improving hotel management service: Evidence of Visegrad group countries. In ResearcheGate, 2019, no. 1, pp. 208-220. https://www.researchgate.net/publication/332174405

Bačik, R. et al. 2019b. The impact of selected quality management attributes on the profitability of top hotels in the Visegrad Group countries. In Polish Journal of Management Studies, vol. 19, 2019, pp. 44-57. http://doi:10.17512/pjms.2019.19.1.04

Bault, 0. 2020. Coronavirus - the V4 react at an earlier stage than Western Europe. https://visegradpost.com/en/2020/03/19/coronavirus-the-v4-react-at-an-earlierstage-than-western-europe/ (Accessed the $20^{\text {th }}$ April of 2020).

Bertelsmann Stiftung. 2018. BTI 2018 Country Report - Kosovo. Gütersloh : Bertelsmann Stiftung, 2018.

Butkus, M. - Mačiulytè-Šniukienė, A. - Matuzevičiūtè, K. 2020. The role of institutions in shaping geography of development disparities across European Union. In Geografický časopis, vol. 72, 2020, no. 1, pp. 27-49. http://doi.org/10.31577/geogrcas.2020.72.1.02

CPI. 2019. Korruptionswahrnehmungsindex. http://www.transparency.de/cpi// (Accessed the $20^{\text {th }}$ April of 2020).
Dangerfield, M. 2008. The Visegrád Group in the Expanded European Union: From Preaccession to Post accession Cooperation. In East European Politics and Societies, vol. 22, 2008, no. 3, pp. 630-667. http://doi:10.1177/0888325408315840

Doli, D. - Korenica, F. 2010. Kosovar Constitutional Court's Jurisdiction: Searching for Strengths and Weaknesses. In German Law Journal, vol. 11, 2010, no. 7, pp. 803-836.

Dugulan, D. - Balaure, V. - Popescu, I. C. - Veghes, C. 2010. Cultural Heritage, natural resources and competitiveness of the travel and tourism industry in Central and Eastern European countries. In ResearchGate, 2010, no. 122, pp. 742-748. https://www.researchgate.net/publication/227367815

Faracik, R. 2014. Which cities are historic? An attempt to define the phenomenon in the context of tourism development opportunities. In: Radics, Z. and Pénzes, J. (ed.) Enhancing competitiveness of V4 historic cities to develop tourism - Spatialeconomic cohesion and competitiveness in the context of tourism. Debrecen : Visegradfund, 2014.

Gollopeni, B. 2015. Rural Urban Migration in Kosovo. In International Journal of Business and Social Science, vol. 6, 2015, no. 9, pp. 1.

Gotev, G. 2019. Visegrad countries back opening of accession talks with North Macedonia, Albania: https://www.euractiv.com/section/enlargement/news/visegrad-countriesback-opening-of-accession-talks-with-north-macedonia-albania/ (Accessed the $20^{\text {th }}$ July of 2020).

Greve, B. 2020. Preparing welfare states in the age of Covid-19. In: Boomgaarden, G. (ed.) 12 perspectives on the pandemic. International social science thought leaders reflect on Covid-19, 2020. De Gruyter.

Holienka, M. - Jančovičová, Z. - Pilková, A. 2016. Youth en-trepreneurship in Visegrad countries. In Entrepreneurial Business and Economics Review, vol. 4, 2016, no. 4, pp. 105-121.

Joireman, S. F. 2017. Ethnic violence, local security and return migration: Enclave communities in Kosovo. In International Migration, vol. 55, 2017, no. 5, pp. 122-135. http://doi: 10.1111/imig.12316

Kohl, H. 2009. Social dialogue, workers' rights and freedom of association in the western Balkans - a survey after a first round of empirical research. In SEER-South-East Europe Review for Labour and Social Affairs, 2009, no. 2, pp. 151-173.

Koinova, M. 2018. Critical junctures and transformative events in diaspora mobilisation for Kosovo and Palestinian statehood. In Journal of Ethnic and Migration Studies, vol. 44, 2018, no. 8, pp. 1289-1308.

Krieken, R. 2020. Covid-19 and the civilizing process. In: Boomgaarden, G. (ed.) 12 perspectives on the pandemic. International social science thought leaders reflect on Covid-19, 2020. DeGruyter.

Kosovo. 2020. About Kosovo: http://www.beinkosovo.com/quick-facts-about-kosovo/ (Accessed the 20th July of 2020).

Light, D. - Dumbraveanu-Andone, D. 1997. Heritage and National identity: exploring the relationship in Romania. In International Journal of Heritage Studies, vol. 3, 1997, no. 1, pp. 28-43.

Mura, L. et al. 2017. Development trends in human resource management in small and medium enterprises in the Visegrad Group. In Acta Polytechnica Hungarica, vol. 14, 2017, no. 7, pp. 105-122.

Péter, Z. - Záhorcsák, Z. 2018. The situation, competitiveness and the development of tourism: the Visegrad countries. In: Kuttor, D. (ed.) Visegrad mosaic - New Colours and old contours. Observing and understanding the spatial features of socio-economic processes in East Central Europe. Miskolc: University of Miskolc, 2018.

Plevák, 0. - Yar, L. - Zbytniewska, K. - Zgut, E. 2019. Transforming words into deeds the Visegrad Group and Western Balkans' EU integration: https://www.euractiv.com/ section/enlargement/news/transforming-words-into-deeds-the-visegrad-groupand-western-balkans-eu-integration/ (Accessed the $20^{\text {th }}$ July of 2020).

Radics, Z. - Pénzes, J. 2014. Enhancing competitiveness of V4 historic cities to develop tourism - Spatial-economic cohesion and competitiveness in the context of tourism. Debrecen : Visegradfund, 2014.

Ramadani, I. et al. 2011. Extension of urban infrastructure in the village of Kosovo. In Procedia-Social and Behavioral Sciences, vol. 19, 2011, pp. 317-321. http://doi.org/10.1016/j.sbspro.2011.05.137.

Rátz, T. 2004. European Tourism. Székesfehérvár : János Kodolányi University College, 2004.

Rickly, J. 2020. An uncertain future for the tourism industry in the wake of Covid-19. In: Boomgaarden, G. (ed.) 12 perspectives on the pandemic. International social science thought leaders reflect on Covid-19. DeGruyter, 2020.

Rowe, G. - Wright, G. 1999. The Delphi technique as a forecasting tool: Issues and analysis. In International Journal of Forecasting, vol. 15, 1999, no. 4, pp. 353-375. http://doi.org/10.1016/50169-2070(99)00018-7 
Schmidt, A. 2016. Friends forever? The Role of the Visegrad Group and European Integration. In Politics in Central Europe, vol. 12, 2016, no. 3, pp. 113-140. http://doi.org/10.1515/pce-2016-0019

Skulmoski, G. J. - Hartman, F. T. - Krahn, J. 2007. The Delphi Method for Graduate Research. In Journal of Information Technology Education: Research, 2007, no. 6, pp. 001-021. https://doi.org/10.28945/199

Smart Insights. 2017. Marketing communications planning using the PASTA model: http://www.smartinsights.com/managing-digital-marketing/planning-budgeting/ marketing-cdommunications-planning-using-pasta-model/?lang=en (Accessed the $20^{\text {th }}$ of April 2020).

Smith, M. K. 2007. European cultural tourism: integration and identity. In Smith. M. K. (ed.) Issues in cultural tourism studies. London and New York: Routledge, 2007, pp. 62-80.

Smith, P.R. - Zook, Z. 2016. Marketing Communications. $6^{\text {th }}$ ed., Kogan Page, 2016.

Sörensen, J. S. 2006. The shadow economy, war and state building: social transformation and re-stratification in an illiberal economy (Serbia and Kosovo). In Journal of Contemporary European Studies, vol. 14, 2006, no. 3, pp. 317-351.

Studzieniecki, T. - Meyer, B. - Wanagos, M. 2018. Discover Central Europe' - Promotion of The Visegrad Group's Cross-Border Tourist Products. In: Klímová, V. - Žítek, V. (eds.) XXI. mezinárodní kolokvium o regionálních vědách. Sborník príspěvků. Brno: Masarykova univerzita, 2018, pp. 482-490. http://doi: 10.5817/CZ.MUNI.P210-8970-2018-63

Tahirsyzaj, A. 2010. Higher Education in Kosovo: Major Changes, Reforms, and Development Trends in the Post-Conflict Period at the University of Prishtina. In Interchange, 2010, no. 41, pp. 171-183.

Taylor, Z. - Ciechański, A. 2020. Ownership transformation and FDI among national carriers operating road passenger transport services in the Visegrád Group (V4) countries. In Geografický časopis, vol. 72, 2020, no. 1, pp. 81-102.

Visegrad Group. 2009. The Visegrad Group stands ready to promote the integration of the countries of the Western Balkans.

http://www.visegradgroup.eu/2009/the-visegrad-group (Accessed the $20^{\text {th }}$ July of 2020).

Visegrad Group. 2017. V4 Foreign Ministers' Joint Statement on the Western Bal-kans. http://www.visegradgroup.eu/calendar/selected-events-in-2017-170203/v4wb6joint-statement (Accessed the 20 $20^{\text {th }}$ July of 2020).
Visegrad Group. 2019. V4 Statement on the Western Balkans. http://www.visegradgroup. eu/documents/official-statements/v4-statement-on-the-190912 (Accessed the $20^{\text {th }}$ July of 2020).

Visegrad Group. 2020a. Aims and structure. http://www.visegradgroup.eu/about/aims-and-structure (Accessed the $20^{\text {th }}$ April of 2020).

Visegrad Group. 2020b. History of the Visegrad group. http://www.visegradgroup.eu/history/history-of-the-visegrad (Accessed the $20^{\text {th }}$ April of 2020).

Visegrad Group. 2020c. Polish tourism sector hit particularly hard by coronavirus - official. http://www.visegradgroup.eu/news/polish-tourism-sector (Accessed the $20^{\text {th }}$ April of 2020).

Visegrad Insight. 2019. Eastern Partnership 2030 Trends. https://visegradinsight.eu/eastern-partnership-2030-trends/ (Accessed the $20^{\text {th }}$ April of 2020).

Wanagos, M. - Smalec, A. - Studzieniecki, T. 2018. Market Monitoring And Its Importance In The Development Of Tourism On A Local Scale.' In: Klímová, V. - Žítek, V. (eds.) XXI. mezinárodní kolokvium 0 regionálních vědách. Sborník príspěvků. Brno : Masarykova univerzita, 2018, pp. 530-535.

Ward, S. V. 1998. Selling Places: The marketing and promotion of towns and cities 1850 2000. London: E\& FN Spon, 1998.

\section{Contact address}

Gabriela Antošová, Czech Technical University, Masaryk Institute of Advanced Studies, Czech Republic, e-mail: gabriela.antosova@cvut.cz ORCiD https://orcid.org/0000-0001-5330-679X 